\title{
Science and Technology in the Ottoman Language of Power (1790s-1910s).
}

Rethinking the State, the Economy, and the Elites

Darina Martykánová

\section{(2) OpenEdition \\ Journals}

Electronic version

URL: https://journals.openedition.org/ejts/6937

DOI: $10.4000 /$ ejts.6937

ISSN: $1773-0546$

Publisher

EJTS

Electronic reference

Darina Martykánová, "Science and Technology in the Ottoman Language of Power (1790s-1910s). ",

European Journal of Turkish Studies [Online], 31 | 2020, Online since 04 May 2021, connection on 19

May 2021. URL: http://journals.openedition.org/ejts/6937 ; DOI: https://doi.org/10.4000/ejts.6937

This text was automatically generated on 19 May 2021.

(c) Some rights reserved / Creative Commons license 


\section{Science and Technology in the Ottoman Language of Power (1790s-1910s).}

Rethinking the State, the Economy, and the Elites

\section{Darina Martykánová}

I pursue my research into these issues in the framework of the research project TRANSCAP: The transnational construction of capitalism during the long 19th century. An approach from two peripheral regions: the Iberian World and the Mediterranean [PGC2018-097023-B-100], funded by the Ministry of Science and Innovation of Spain and directed by Juan Pan-Montojo and myself. I thank Houssine Alloul, Erdal Kaynar and the two anonymous reviewers for their thoughtful comments.

1 In the early twentieth century, the governor of Kosovo told Mustafa şevki, the young engineer-in-chief of the province, to build him a nice and scientific bridge (güzel ve fennî bir köprü) (Atayman 1984). What did he mean by that? As they say, beauty is in the eye of beholder: while it is widely recognised that it is at least partially dependent on cultural expectations, beauty is open to interpretation and is notoriously hard to measure. To the contrary, science and technology imply measurability and capacity to reproduce the results. What was on the governor's mind when he asked for a "scientific" bridge?

2 The governor Mahmud şevket Pasha (1856-1913) was an outstanding Ottoman military commander and statesman. He was educated in the Mekteb-i Harbiye (the Military Academy, arguably the most prestigious Ottoman higher education establishment of that time). After a distinguished career under the sultan Abdülhamid II (1876-1908), he ended up endorsing the Young Turk Revolution (1908) and was commander of chief of the 'Action Army' that put an end to the counterrevolutionary uprising in 1909. He displayed an inclination towards technological change. He was, allegedly, the first person to bring an automobile to the Ottoman capital, though this might be a legend based on the fact that he was assassinated while travelling in one. Nonetheless, his support for new technology went beyond the anecdotic: as Minister of War, he 
promoted the development of military aviation in the Ottoman Empire, particularly for military purposes. (Kapucu, Palabıyık 2008: 85)

Besides taking to consideration the profile of the governor and his later support for technological innovation, we can approach the issue the other way around, by focusing on the man whom he was giving such an order to. His interlocutor was a public employee, an engineer who held a post in the provincial administration of public works. He was also a young man who had graduated from the Hendese-i Mülkiye Mektebi, Civil Engineering School, a state school founded in 1883 to train engineers for public administration, in particular the Ministry of Public Works. These engineers were civilians, but until the Young Turk revolution the school was under military tutelage. Its graduates later attributed the raison d'être of this measure to the wish of Abdülhamid II's government to prevent non-Muslims from entering and thus foster the presence of Muslims at high-ranking technical posts in the Ottoman Administration for which the school was designed to cater (Uluçay, Kartekin 1958: 131-134). Before the revolution and during the Second Constitutional Period (1908-1920), public image of the school and its students was linked to constitutionalism and modernisation, in a similar way as the Harbiye or the Tlbbiye, the Imperial Academy of Medicine (Uluçay, Kartekin 1958: 184-185). One of the reasons why these schools were considered the hotbeds of revolution was the fact that their curricula included modern education in sciences such as mathematics, physics, chemistry, medicine etc. In the imagination of the public, the staff, students and graduates were therefore particularly inclined towards modernising reforms. In fact, our young engineer was approached by two members of the Committee of Union and Progress, who invited him to join it (Martykánová 2014). These two conspirators were officers, graduates from the Harbiye, who must have thought that Mustafa şevki, a fellow graduate of a prestigious state school, a man of science and an engineer serving in a strategical province, would be an ideal candidate to join the opposition against the Hamidian regime. Our engineer was, however, less than enthusiastic about the prospect, fearful of punishment. He argued that he was already serving the patriotic cause by doing his duty as engineer in charge of public works (Atayman 1984: 37-41). This invitation to conspiracy gives us a hint on how a man like Mustafa şevki must have been perceived by his contemporaries, so we can better interpret the words the governor chose in order to convey his desire for a bridge to be built.

4 The governor's choice of words seems to have stayed with the young engineer. When local notables wanted to scrap the project due to its costs, the engineer reminded them of the governor's wish to have the bridge built in a "scientific way" (köprüyü fennî bir şekilde inşaat etmek) (Atayman, 1984: 30-31). This is an important clue: the notables' opposition stemmed from the high costs of the bridge as it had been planned by Mustafa şevki and the engineer did not defend himself arguing that his "scientific" bridge would be cheaper than a common one. Therefore, by using the word "fenni", the governor might have implied that he was willing to invest a sum surpassing the cost of a "common" bridge. Even if the governor did not imply such a thing, Mustafa şevki could credibly argue so before those who opposed his project. Why would the governor do that, in times of indebtedness and scarcity? If the authorities were willing to invest public money in new construction technology that was more costly than the traditional way of building bridges, we can assume that they expected the resulting infrastructure to be more durable (resistant to floods and weather) and efficient, for instance in terms 
of being able to carry more load and resist busier traffic. While the notables might have been thinking about the immediate costs, the engineer might have been considering the long-term benefits. Getting such glimpse into an ordinary, everyday communication in the Ottoman provincial administration permits us to speculate about the implicit meaning of concepts such as "fenni", which the governor seemed to have shared with the engineer. This little story shows that the two men considered "scientific" ways of proceeding both necessary and superior to the old, "routine" ways, even if the initial costs might have been high, in both literal and symbolic sense.

This language shared by representatives of the Ottoman governing elites in the early twentieth century, had deep roots. Ilm and fenn were concepts embedded in the Islamic thought that underwent important transformations during the eighteenth and nineteenth centuries. In my article, I will not offer a systematic insight into the conceptual transformations of $i \mathrm{~lm}$, as this is a gigantic enterprise that has yet to be undertaken, preferably by researchers familiar with Muslim philosophy and religious thought. Moreover, there is plenty of room for exploration of the use of this concept in the language of power and politics before the nineteenth century, in the line of the existing works on the Ottoman languages of power in that period (Sariyannis 2019; Ferguson 2018). Here I will instead focus on its less highbrow sister, fenn (or fen): the meanings and mutations of this concept may seem narrower and less challenging, but they are closely linked to what I find particularly interesting: the rise of a technocratic logic as part of the state-building process. While most studies underline the importance of 'science' in late Ottoman history from an intellectual history approach, this article shows how the reference to science ${ }^{1}$ had an institutional framework and led to consolidation of distinct groups of experts beyond the state. While I avoid the term technocracy that implies stable institutional structures in which experts systematically intervene in the decision-making, I understand technocratic logic as the introduction of technocratic elements (i.e. creation of technical bureaus, expert and mixed committees in parliaments, ministries and municipal councils, a requirement of a diploma in a specific field for specific posts in the Administration, recruitment of public employees via a concours, an official examination assessing the candidates' expert knowledge) into the government and, particularly, into the administrative apparatus (on technocracy: Picon 2007; Porter 1995; Bocquet, Fettah 2007; Bourdieu 1989).

\section{Fenn in the art of war and in the art of government}

While ilm has always had a busy and multi-layered life on its own in the Ottoman thought, the couple ulûm-ve-fünûn appeared frequently in all kinds of texts during the long nineteenth century, their meaning and use not dissimilar from the "Latin" European notion of "arts et sciences", "sciences and arts" or "ciencias e artes", consecrated in the influential and emblematic work of the French - or francophoneEnlightenment, the Encyclopédie, ou Dictionnaire raisonné des sciences, des arts et des métiers. In fact, the similarity consisted even in the blurred differentiation of the two terms in the Ottoman and in the European context: Ismail Kara and Göksun Akyürek, among others, have shown how ilm and fenn were often used interchangeably, even if some dictionaries and other sources from the second half of the nineteenth and the first third of the twentieth century strove to establish a difference between a more abstract theoretical ulûm, and more practice-oriented, applied fünûn (Kara 2003; 
Akyürek 2011: 29-32). ${ }^{2}$ This was, I would argue, also the case of the "sciences and arts" in many European languages well into the nineteenth century. Despite the formal differentiation between the two in dictionaries and encyclopaedias, the meaning in the common use continued to overlap: geometry, mathematics or medicine, for instance, could be called art and science in different places of the very same text in French, Spanish or English at least to the mid-nineteenth century, while, at the same time, art (or arte) could also overlap with métier (or oficio). ${ }^{3}$ This kind of plurality continued notwithstanding the fact that the use of art or arte to refer to beaux-arts rather than métiers and industrial pursuits was clearly on the rise in Europe.

7 There is little research on the concept of fenn regarding the period before the end of the eighteenth century, although the word had been used for centuries. It is well known, for instance, that the famous sixteenth-century Ottoman architect Mimar Sinan used both fenn and san'at to define architecture. Nonetheless, systematic analyses still must be done. Therefore, my findings, particularly those concerning the last two decades of the eighteenth century, should be interpreted very carefully, as future research on the previous use of the term can seriously alter my tentative interpretations. Moreover, I focus almost exclusively on the use of the word in internal administrative documents aimed at circulating in very restricted circles of men of action who served the sultan, leaving aside texts aimed at broader intellectual public.

Examining administrative documents in Ottoman Turkish from the late eighteenth and early nineteenth century, we find that very often, ilm and fenn were used interchangeably - like science and art in Europe at that time; such as ilm-i hendese or fenn-i hendese for geometry. This continued being true in the mid-nineteenth century when Ottoman authorities addressing sending students abroad to receive training in medicine, referred to it interchangeably as ilm and fenn. ${ }^{4}$ Nonetheless, when there was a difference, then it consisted of the word fenn being associated to more practical activities, while ilm was linked to abstract knowledge (Martykánová 2010: 107). In this sense, fenn bore a meaning similar to that of ars, art or arte in several European languages during the same period. Thus, for example, in the Ottoman version of Seyyid Mustafa's Diatribe sur l'état actuel de l'art militaire, du génie et des sciences, the author writes about the need for geometers/engineers in the art of war (fenn-i harbde mühendislerin lüzumunu) confirmed by "many examples and experiences". ${ }^{5}$ Ars belli, that is, the art of war, was a common expression in many languages in Early Modern Europe and was used well into the nineteenth century. Moreover, fenn as well as ars included not only the notion of practice, but sometimes also that of craftwork. Thus, fenn could be used in reference to the same practices as the word san'at, that is, art, craft, while ilm would not be used interchangeably with san'at. ${ }^{6}$ The documents referred, for example, to the art of cartridge making (fenn-i ateşbaz) as well as the naval arts (funûn-i derya) or "naval art including map-making, geography and navigation". ${ }^{7}$ Aynur Erdoğan has shown that this trend continued in the Tanzimat period, when - in the documents concerning the Ottoman government policy of sending young men to Europe to train in useful activities - fenn could refer to civil and naval engineering, topography or lithography as well as processing of iron and fabrication of gunpowder, while san'at was used to refer to gunpowder and lithography techniques, but also to tailoring and leather-processing (Erdoğan 2013). There was an overlap between ilm and fenn and there was an overlap between fenn and san'at, but there was hardly any overlap between ilm and san'at. 
9 At least since the late eighteenth century, the Ottoman authorities identified specific sets of knowledge and practices that entered in the realm of ulûm-ve-fünûn (such as shipbuilding techniques, fortification styles or military drill) as "new" (yeni, cedid) and at the same time as "European" (Avrupalı or Avrupaî or tavr-i efrenci). ${ }^{8}$ Systematic introduction of novelties from abroad was explicitly acknowledged in terms of language (nizam-i cedid being the best known and most striking example of this). To quote an example, in 1797, the Grand Admiral of the Ottoman Navy Küçük Hüseyin Pasha (1757-1803) interpreted the actions of Ottoman statesmen in the past years in following terms: the sultan had asked the French authorities to send an expert in the "art of shipbuilding" (sefine inşaası fenni) to give new impulse to naval education and to see to it that "ships would be built similar to those that were invented and designed in European countries according to the laws of geometry to be used in war and in peace, [ships] that are managed with great ease." 9

In the internal administrative documents related to the academies of geometry (hendesehane) founded to provide training at different levels to navy men, artillerymen and fortification officers, Ottoman statesmen expressed the need for men who would have a good command of theoretical knowledge and who could, at the same time, carry out specific military tasks. These men were defined both as mühendis (geometersengineers) and as mütefennîn, a term that is presumed to be of recent coinage and is derived from the word fenn that is perhaps best translated as technicians or men who applied scientific knowledge in practical, useful tasks. These terms were sometimes interchangeable, but while mühendis could, at that time, mean a teacher of geometry rather than an engineer, mütefennîn does seem to place more of an emphasis on application or practice (Hitzel 1995; İhsanoğlu 1992). The example of the two labels being used interchangeably, concerns, for instance, the men of higher rank among the French experts sent by Louis XVI to help improve the Ottoman fortifications, artillery and navy by introducing new techniques and reforming the training of officers. These missions included master artisans and non-commissioned officers, but the leading figures were military and naval engineers (ingénieurs du roi André-Joseph Laffite-Clavé and Joseph-Gabriel Monnier de Courtois, and ingénieur constructeur de vaisseaux Jacques Balthasar Brun de Sainte-Catherine), which in the France of that time implied certain social standing. These "learned" officers, who had received formal training in prestigious schools (École royale du génie de Mézières and the école de Marine, respectively), were referred to as both mühendis and mütefennîn in the Ottoman documents produced during and after their stay in the Ottoman Empire. ${ }^{10}$

11 The word continued to be used, though not frequently, in the nineteenth-century Ottoman administration, for instance to label those students at the Military Engineering School who were to receive a more detailed scientific education than the artillery students in order to become fortification officers, as we can appreciate in the school reform outlined in the lâyiha of Bekir Pasha, director of the Mühendishane-i Berrî- $i$ Hümayûn, Military School of Engineers, dating from 1847.11

While mütefennîn was rarely used, in the Ottoman bureaucratic parlance the references to the notion of fenn proliferated and even acquired material, institutional forms. Permanent or temporary "technical (or, expert) commissions" (sing. heyet-i fennîye, fen heyetleri) were established so local and foreign experts could provide their opinion on different specialised subjects, particularly related to the new concept of government's systematic transformative intervention, the nafia, or beneficial actions and works. We 
have to bear in mind that the men who took part in these commissions as experts were acknowledged as such mostly due to their experience in a given field of action. It was their previous practice in a specific field that implied that these men held specialised knowledge that could be used in the process of providing advice and making decisions, rather the specialised knowledge implying that they had the capacity to carry out practical tasks. Besides having practical experience in a specific field, these experts could be in possession of formal credentials such as an official title or a diploma, but this was far from being an essential requirement (Martykánová; Kocaman 2018). The most common exception to this prevailing pattern were Ottoman Muslim men who had studied or received specialised training abroad or in the Empire: these men were indeed often included for their expert knowledge, even if they lacked a professional trajectory to prove that they could put their knowledge to practice. Nonetheless, the importance of formal credentials grew towards the end of the nineteenth century, part of a general, global trend towards the credentialism in professions that were understood as based on high-level technical and scientific knowledge (Martykánová; Kocaman 2018; Martykánová 2014).

\section{Nafia: from beneficial actions to public works}

The general framework of expanding government intervention in the mid-nineteenth century can be understood through the concept of nafia. As Alper Yalçınkaya points out, the notion of useful knowledge -or beneficial knowledge, I would emphasise- was by no means a novelty adopted or developed in the nineteenth century, but had been used in the Classical Period, too. The examples he gives from the past mostly indicate an understanding of useful knowledge in terms of Muslim faith and religious practice, knowing the right from wrong (Yalçınkaya 2015: 95). However, it is true that medicine or artillery were also traditionally defined by the word nafi. While, as Yalçınkaya shows, this understanding was still alive and well in the late nineteenth-century Ottoman thought, there is no doubt that the most common understanding of useful sciences (ulûm-i nafia) and useful activities (umur-i nafia) among the Ottoman bureaucrats and intellectuals evolved towards something quite different, particularly due to the implicit and explicit links to government action.

14 The concept of nafia itself has received some attention by historians of Ottoman political thought, economic historians, historians of architecture and historians of concepts. The different interpretations present a variety of nuances that are sometimes contradictory, but often easy to combine and reconcile. Niyazi Berkes has argued that the term nafia, which was later understood mainly as amelioration through public works, referred in the 1820s-1840s to beneficial acts in general, to different ways of amelioration, from the mobilisation of resources to the spread of education, as well as to the support of commerce, industry, and agriculture. It built on the traditional role of the sultan as protector of his peoples and as a guarantor of justice and order, which was redefined to include new forms of active intervention: through amelioration, his role as benefactor of his people was stressed, as well (Berkes 1978). Tekeli and İlkin stress different aspect of the concept: the benefits for the government, rather than for the subjects. They point to the fact that the concept of nafia is related to terms such as profit, benefit, outcome, which connects it to the traditional fiscalist concerns of the Ottoman dynasty and the government officials who served it. In this sense, it would 
also display important continuity with the past worldview of the ruling elites (Tekeli, İlkin 1994). Sariyannis also stresses the understanding of nafia in terms of benefit, but unlike Tekeli and ilkin interprets the acknowledgement that the policies under the umbrella of nafia were profit driven as a sign of novelty. He interprets in, in a way, as a sign of a new legitimacy of profit-seeking activities, and opposes it to the earlier emphasis on umran and slah as concepts legitimising governmental intervention that appealed to the common good (Sariyannis 2013).

While the three interpretations seem to be contradictory, it may be possible to, at least partially, reconcile them. First, the fiscalist understanding of governmental action does not need to disappear completely with the development of economic thought that includes a broader promotion by the ruling elites of profitable activities in the realm. Second, there is no necessary contradiction between the emphasis on the interests of the dynasty or the state (devlet) and the benefits for the subjects (on the changing concept of devlet, Sigalas 2007). The notion that what was good for the dynasty or state was good for the subjects has been a commonplace in the discourse of ruling elites in the eighteenth and nineteenth century, in the Ottoman Empire and in Europe. In her recent work, Camille Cole shows how these two concerns combined in the Hazine- $i$ hassa's (the sultan's Privy Treasury) attempts to "revive" (ihya) the land in Iraq to produce public - as well as private- benefit, an example that is particularly interesting for the purposes of this article because the aim was to be achieved using technology, specifically steamships (Cole 2021).

The concept of nafia was further enriched by a growing understanding of governmental action in the framework of competition among global powers: a notion of the world composed of competing powers that needed to maximise their performance in order not to perish. By the late 1830s, the notion of imperial competition expanded far beyond the limits of the military, and came to include mobilising resources in areas like agriculture, industry, and commerce, as the institutionalisation of the concept of nafia clearly demonstrates (Mardin 2018). Thus, for example, the Ottoman ruling elites founded a council in 1838 under the name the Council of Commerce and Agriculture (Meclis-i Ticaret ve Ziraat) that was renamed as Meclis-i Umur-i Nafia a year later. To translate its name as "Council of Public Works" would be, in my opinion, anticipating the historical development of the concept of nafia. The fact that the council's original name pointed to the purpose of promoting commerce and agriculture rather that the construction of public works, invites to the translation in line with the abovementioned historiographic debate as Council of Beneficial Matters or Useful Activities.

As for the nineteenth century evolution of the concept, Abdülhamit Kirmızı has stressed how the concept of nafia became intertwined with the notion of terakki, that is, progress (Kırmizı 2012). At a transnational level, and in the Ottoman thought, the concept of progress in the nineteenth century was understood in a twofold way: as a process that characterised the Mankind as a whole, but also as active action to be taken not to fall into decadence and disappear. As nafia became linked to progress, it acquired a horizon of expectation, in Koselleckian parlance, a long-term temporal dimension that went beyond the immediate benefit for the state and/or the subjects (Koselleck 1993). As it became inscribed in a narrative of durable development of the realm, with an implicit reference to the ongoing inter-imperial competition, the concept acquired certain autonomy from the interests of the ruler (or dynasty), but not so much from the ruling elites who positioned themselves as those who knew what was needed for the 
Empire to progress and as those capable of defining and leading the suitable progressoriented actions. In this sense, an interesting parallelism can be made between nafia and the contemporary Spanish concept of fomento. The latter evolved from a promotion of "the wealth of the realm and happiness of the subjects" in the framework of the late eighteenth century Bourbon imperial reformism towards the notion that the state and qualified public employees- had an essential role to play in eliminating the material and legal obstacles to profit-producing private initiative (for example, by building road, improving ports and subsidising the railways) and, in case of its weakness, to complement it with its own vigorous action to give a boost to the country's economy, mainly through public works (Martykánova, Pan-Montojo 2020). In the Ottoman case, the concept of nafia became gradually reduced to mean "public works" in the language of the public administration. The proof of this trend can be found not only in the bilingual documents that in the second half of the nineteenth and the beginning of the twentieth century translate nafia as travaux publics, but also in the fact that the corresponding ministry was often called Ticaret ve Nafia Nezareti (Ministry of Commerce and Public Works) and a Ministry of Agriculture existed in parallel. Thus, the promotion and improvement of agriculture and commerce, that in the 1830s had been in the very centre of the concept of nafia, had to be listed separately by the last third of the nineteenth century, as another function of an institution that had nafia in its name.

Arts and sciences (ulum ve fünûn) were in the core of the discourse of improvement that developed around the concept of nafia. Connecting with the more narrowly oriented reform effort in the last third of the eighteenth century, for the mid-nineteenth century Ottoman reformers to improve the state of the Empire was to involve more or less systematic efforts to develop, import, adopt and adapt scientific and technical knowledge, know-how and objects, and use them efficiently in the growing number of strategic fields that were supposed to require governmental intervention. When the above-mentioned Meclis-i Umur-i Nafia was put in place in the late 1830s, the Ottoman official newspaper Takvim-i Vekâyî published a praise of sciences and arts, implicitly legitimising governmental intervention via public works:

The sciences (ulûm) and the letters (maarif) [...] are a factor of power and of happiness, a just reason to be proud and glad, and a source of wealth and of fortune for the men; that is a fact proven both by the reason and by the [divine] revelation. The science (ilim) is in the origin of all sorts of existing and known industries and crafts. In the same way as the religious sciences (ulûm-i diniye) bring eternal salvation, the other sciences (fünûn-i sâire) offer a better existence to men (quoted in Kara 2003: 33).

By the late 1860s, science was defined as one of the pillars of civilisation and a systematic link was established between its reified forms such as public works, on the one hand, and progress, on the other:

The sciences (fünûn) and letters (maarif) are the fundaments of world civilisation. It is precisely science and knowledge (ilm ü marifet) that engender progress. ... Science and knowledge (ilm ü marifet) are at the origin of the inventions and of the execution of public works in the domain of arts and crafts of industry, and these operate to create means and techniques that facilitate the satisfaction of the basic needs of human society. Therefore, civilised nations and peoples that aspire to share the wealth of the world do not have any other choice than to follow the progress of humanity. ${ }^{12}$ 
Historians have often accepted the assessment made by contemporary Ottomans (ever since Ibrahim Müteferrika's Usülü'l-Hikem) and Europeans who argued that sciences and arts were a key factor in military success, economic prosperity and geopolitical competition. I would caution against automatically endorsing this view and assuming that scientific and technological innovations played an important role in the relative deterioration of the geopolitical position of the Ottoman Empire that did indeed take place in the eighteenth and the nineteenth centuries. If there is indeed such a connection, it has to be proven, not dogmatically stated. Nonetheless, the central role attributed to sciences and technical innovations by the reformers is something to be explicitly acknowledged; although, in my opinion, it is neither surprising nor hard to explain. Unlike the Orientalist clichés would invite us to believe; Ottoman elite men neither ignored nor disdained scientific and technical innovations. Quite to the contrary; as, among others, Feza Günergun or Benjamin Fortna have pointed out, they showed great interest in them early on (Günergun 2011; Fortna 2002; Kaçar 2000). In his report dated to $1791 / 2$, the Ottoman statesman and ambassador to Vienna Ebubekir Rattib Efendi attributed the fact that a small continent such as Europe became the "centre of the human power due to the progress (ilerleme) of the arts and sciences". ${ }^{13}$ Perhaps, the Ottoman elites even overestimated the contribution of scientific and technical innovations to Europe's growing geopolitical and economic might. I suggest that the link the Ottoman ruling elites and patriotic intellectuals systematically established between ulûm ve fünûn, on the one hand, and political power, on the other, is due to the following reasons: sciences were traditionally construed as elite knowledge, and both the Ottomans and many of their contemporaries from Europe understood that technology was an application of sciences, derived from scientific principles. Therefore, focusing on science and technology did not, in principle, challenge the traditional distribution of power between the men of the State, on the one hand, and the reaya, on the other hand, nor did it require the elites to share power with larger groups of population. Since the 1830s, there was a more widespread understanding that an effort should be made to include the "common" people in the project of spreading the Lumieres, ${ }^{14}$ but the hierarchy was clear: the elites were to manage the appropriation of knowledge, as well as of its top-to-bottom transmission via education and training. Once again, Ottoman learned patriots, to borrow Alper Yalçınkaya's expression, seamlessly blended their traditional understanding of the hierarchy of knowledge with the transnational discourse of the progress of civilisation (Yalçınkaya 2015).

\section{Men of science, men of action}

21 The trend of expanding government intervention and making use of experts in the newly addressed areas culminated in the development of a full-blown nafia administration. Different ministries and administrative bodies employed fen memurlarl, public employees that were at the same time experts in a specific field that was considered to require technical and/or scientific knowledge. They were often organised in fen kalemleri, technical bureaus that were part of different public institutions (such as Ministry of Public Works, Ministry of Posts and Telegraphs, Ministry of Agriculture or municipal government of a city). Their aim was to provide a stable, consolidated pool of expertise for the governing elites to perform tasks such as advice in political decision- 
making, control of investment and supervision of the concessionaries who tended to be in charge of actually carrying out government policies, including the construction of infrastructures. These men were first mostly trained via the traditional masterapprentice system within the administrative structures by a local or foreign expert (an outstanding example would be the French Émile Henri Lacoine's contribution to the training of Ottoman experts on telegraphy), and sometimes sent to broaden their education abroad. Internal documentation produced by the different bodies of the Ottoman Administration often referred to tahsil-i fünûn (training in techniques or useful sciences) when discussing the policy of sending young men to Europe to obtain knowledge and skills in fields that the government officials considered as applicable and useful for the State, and, depending on the "art" to be acquired, these stays could either take the form of workshop training or education in institutions of higher education (Erdoğan 2013). Towards the end of the nineteenth century, a previous specialised education at a school became more common for these technical public employees (fen memurlarl). The proliferation of such technical bureaus in central, provincial and municipal administration meant a strong boost for the figure of the Ottoman Muslim engineer beyond the armed forces, a profile that could hardly exist and reproduce without building upon the established figure of the civil servant (memur).

In the later decades of the nineteenth century, but particularly after the Young Turk Revolution, fenn did not remain on the margins of the redefinition of the relationship between the state and the people, due to the emerging notions of public, nation, citizen and public opinion. Besides the fen memurlar in the sense of expert public employees, a notion emerged of erbab-ı fenn. This notion can best be translated as men of useful science. Ottoman engineers, architects, physicians and science teachers united forces under the umbrella of the common identity of erbab-1 fenn, anchored in their work defined as a combination between an applicable scientific theory and practical, useful skills. For a man to be included to this category, it was not necessary to serve the state, the credentials were acquired in multiple ways that included holding a fenn-related post in a public institution but extended to holders of technical degrees and diplomas and to men who performed a job or profession that was considered as requiring specialised techno-scientific knowledge.

23 Fenn remained a polysemic term throughout the period. Ismail Kara's pioneering chapter has pointed to the continuing partial overlaps between ilm, maarif, fenn, hikmet and san'at up to the very end of the Ottoman Empire (Kara 2003). Daniel Kolland's work on the emblematic journal Servet-i Fünûn, (Wealth of Arts), shows how even a single periodical produced and reproduced several meanings of the notion of fünûn: general knowledge (otherwise expressed by the term maarif), expert skills, fine arts and all kinds of aesthetical undertakings while also being used as synonym of ulûm or "sciences," and also to convey the late nineteenth century transnational concept of "technology" (Kolland 2016). Göksun Akyürek has shown that while there was no clear differentiation between ulûm and fünûn in the everyday use of both terms in written documents in the late Ottoman and the early republican period, there was indeed an effort to differentiate them by individual authors and in dictionaries. For instance, the 1861 edition of the renowned Redhouse dictionary defined fenn as ilme merbût ve menût olan san'at that, taken to consideration our previous analysis of terminological overlaps and differentiations, could be translated as an "art linked and connected to science" 
(Akyürek 211: 31). ${ }^{15}$ Overall, despite the great variety of actual use, when a formal definition was given the pattern consisted mostly in attributing practical aspects and applications to fenn, while ilm was considered more abstract or theoretical. Nonetheless, there was also another line of interpretation: while ilm would include both "classical" and "modern" knowledge, fenn was occasionally interpreted as modern knowledge and skills, particular of the current times or specifically of European origin (Akyürek 2011: 29-43; Kara 2003). Clear calques from European languages, particularly the French, also proliferated, such as the translation of beaux-arts as fünûn-u nefise.

The practical, applicable dimension of fenn as well as its link to the needs of "current times" and the drive to get up to date (muasirlaşma) seems apparent from its use when translating European scientific terminology: économie tented to be translated as fenn- $i$ idare o fenn-i idare-i mülkiye, stressing the aspect of government as well as management of property, in a way that evocates the broad sense of the ars governandi. This was the case, for example, of Mehmed Midhat's 1869 typically creative translation Ekonomi Tercüme: Fenn-i idare of Otto Hübner's work. ${ }^{16}$ Bedi Nuri (1872-1913), Ottoman intellectual and bureaucrat - and a Mülkiye graduate- used ulûm for social sciences (ulûm-i ictimaiye), ilm/ulûm for sociology and both ulûm and fenn for economics (ulûm-i iktisadiye and fenn-i idare). ${ }^{17}$ The practical, technical nature of fenn versus a more abstract and theoretical ilm appears in another example related to the notion that societies can be studied to be better managed.

While the terminological overlap was constant, I would argue that a substantial differentiation did occur in the institutional nomenclature. Fenn, not ilm, became clearly linked to the institutionalisation of interventionist policies when they were supposed to require expert and useful knowledge and skills. Fen kalemleri (technical bureaus), fen heyetleri (expert committees) and fen memurları (technical/expert public employees) proliferated at the Nafia Nezareti (translated systematically to French as Ministère de Travaux Publics), as well as ministries that were, in one moment of another, in charge of agriculture, posts and telegraphs. They also became part of municipal administration, particularly with urban reforms and the development of public infrastructures.

The preference for fenn concerning government-funded institutions went beyond the institutionalisation of administrative bodies. A particularly interesting example would be the final choice of name for the Ottoman university. The Ottoman authorities did not go the way of reforming the education in the madrasah (medrese). In certain sense, they opted mostly to create and fund special schools with the purpose to train state employees, civil or military, like France or Spain (though in case of these two empires, jurists that were over-represented both in politics and in civil service, were universitytrained). These schools were called exactly that: mekteb, a school (Mekteb-i Mülkiye, Mekteb-i Harbiye, Mekteb-i Tibbiye or Mekteb-i Hendese-i Mülkiye), with the exception of the oldest among them, the Military Engineering Academy, Mühendishane-i Berrî Humayun (Mühendishane-i Bahrî Hümayun was renamed as Mekteb-i Bahriye, though). Its name (the house of geometers) had deep roots in the eighteenth-century semistructured training of expert staff within different "bureaucratic households" of the Ottoman government (Martykánová 2010; Kaçar 2000). Going back to the general pattern of these state schools, a particularly relevant example is that of the Mekteb-i Mülkiye, as its full name was, in fact, Mekteb-i Fünûn-i Mülkiye, or the School of Public Sciences, pointing to the notion that training in a set of expert knowledge and skills 
was useful for future government officials and public employees. On the other hand, the Harbiye was sometimes listed as Mekteb-i Ulûm-i Harbiye, ulûm stressing the superior military knowledge in contrast to the more basic one taught in its preparatory school, Mekteb-i Fünûn-i idadiye (founded in 1846). The shifting emphases characterised the use of both concepts throughout the long nineteenth century.

While state schools for future military staff and public servants were more or less successfully set up, a university that would provide scientific education to people not necessarily destined to work for the state, did not seem to be a priority for the Ottoman rulers until quite late. There were intermittent attempts at founding a modern university in Constantinople since the mid-nineteenth century. Before the institution was actually put in place, it had already had a name: Darülfünûn, that is, the House of Sciences (fünûn being the plural of fenn) (Akyürek 2011: 71-109; Dölen 2009). In fact, this choice was far from obvious, Darülulûm being another viable option. In 1866 Indian Islamic scholar Muhammad Qasim Nanautavi founded with several other thinkers an Islamic university known as Daroluloom in the city of Deoband. A less than a decade later, Dar al-Ulum was the name given to an institution of education created in 1871 in Egypt to provide students with both Islamic and "modern" education. However, the Ottomans were not the only ones to go for fenn when naming newly founded institutions of higher education in the mid-nineteenth century. It is quite interesting that the neighbouring Persian Empire opted for the Daralfonun to name an elite school founded by the royal vizier Amir Kabir. According to Encyclopedia Iranica, "in his initial letter of instruction to Jān Dāwūd, first secretary at the Persian legation in St. Petersburg, in August 1850, Amïr Kabīr stressed the military and technical nature of the subjects to be taught at the new academy" ${ }^{18}$ His orders were followed and the school's name has been often translated as the Polytechnic, reflecting well on the fact that military arts (cavalry, artillery etc.) and engineering, as well as medicine, pharmacy and mineralogy were taught there. Moreover, the first teachers were Austrian army officers (including ethnical Czechs and Italians), soon to be joined by Italian army officers. ${ }^{19}$ The Ottomans already had their Harbiye and Tibbiye that provided higher education in military sciences and medicine, so Darülfünûn was not to be another Polytechnic producing elite "learned officers" and bureaucrats with a technical expertise. Rather, it was something between an academy of sciences and a university. However, neither the Ottoman not the Persian institution was an attempt at an "Islamic synthesis," unlike in India or Egypt. The Ottoman school was to provide education "to anyone who in order to complete the human improvement had a desire to learn and obtain all ulum ve fünûn," and the lectures were heavy on natural sciences, but did not include traditional Islamic ulûm taught in the medrese..$^{20}$ The Persian and Ottoman choice of fünun thus strengthens the hypothesis of fenn as something close to the notion of an applied science or "an art linked to sciences", as well as a "modern" science, but not necessarily new or imported from Europe. As we have observed, fenn- $i$ mimari had been used for centuries for architecture, so the point might be in the nineteenth-century use of fenn as implying acknowledgement that this particular kind of knowledge was prone to innovation and development in time, besides being applicable and useful. It may also be relevant to stress that in the cases of Persia and the Ottoman Empire, the impulse to found a darülfünûn came from government officials, unlike in India, where the Daroluloom was an initiative of a group of influential religious thinkers and intellectuals. 
The applicability of fenn and its progressively changing contents that made it useful in the current times is well-reflected in the identitarian category of erbab-ı fenn, which had precisely that specific meaning and with it came the entitlement to authority. It referred to men who had broad knowledge of sciences and used this knowledge when carrying out tasks that were considered as useful. Their actions acquired new meaning in the interaction with the patriotic discourse: "We consider working for the exaltation of our patria continuing in our profession (mesleğimiz) to be a sacred duty (vazife-i mukaddese)." ${ }^{21}$ While they claimed exclusive access as erbab-ı fenn to certain types of professions, posts and duties, at the same time, they were concerned about fenn being made accessible to the people. This concern is clearly articulated in the polemic between several erbab-ı fenn, particularly Mehmed Refik and Aram Margosyan about Ottoman "scientific terminology" (rumuzat-i fenniye) and its improvement (rumuzat- $i$ fenniyemizin islahl). The debate focused on whether learned or popular Turkish or foreign terms should be used and whether the symbols should be in Latin or Arabic characters. ${ }^{22}$ The most passionate promoter of the popular Turkish terminology was Mehmed Refik, electrical engineer from an elite bureaucrat family educated in the Belgian Institute de Montefiore and director of the Civil Engineering School. Tellingly, Mehmed Refik later chose the surname Fenmen when the surname law was adopted in Turkey (Akbaş 2007-2008). There were several stakes in such a discussion: firstly, the participants were concerned about professional education and credentials as well as about standardised and intelligible language of communication among peers and also with the workers. What's more, it also had to do with the effort of broader Ottoman elites to popularise sciences (ulûm ve fünûn) among the people. As Claire Fredj's work has shown for the Ottoman medical professionals and students, this kind of concern was part of constructing and legitimising different nationalist discourses in the linguistically plural world of the Ottoman intellectual elites (Fredj 2014).

This popularisation effort would have a collateral benefit of fostering people's respect for the erbab-ı fenn's work and support for their authority not only at their posts and jobs, but also in the public debate. Physicians, engineers, architects, and teachers, the erbab-l fenn of the Second Constitutional Period aspired to have a broader influence, searching for legitimacy as experts through public recognition in the context of a parliamentary regime. Their expert knowledge and skills served as a basis for their claim to be taken into consideration as policymakers, in a broad vision that organically integrated technical expertise into political economy. Thus, for example, Mehmed Refik defended as a mathematical truth (hakikat-ı riyaziye) that, for Ottoman agriculture and mining industry to progress, the Ottoman lands needed a network of communications. The reformers of Family Law justified the prohibition of child marriages in the 1917 Hukuk-i Aile Kararnamesi by several arguments, including "scientific discoveries" regarding the damage to children and young mothers due to early marriages and childbirth, discoveries that encouraged a change in laws and practices (Martykánová 2009).

\section{Conclusions}

The Ottoman ruling elites' consideration of sciences and arts (ulûm-ve-fünûn) as one of the key elements of European success and an important part of their own reform effort was by no means a late discursive import. The efficiency of mobilising the notions of ilm 
and fenn might have had to do with their well-established place in the thought of the Ottoman elites at least since the eighteenth century, and, at the same time, the prominent position of "sciences and arts" among the criteria of civilisation, a rapidly globalising concept that had emerged in the framework of European Enlightenment. Moreover, attributing importance to sciences and arts also fit in well in the elites' worldvision that included the understanding of the necessary transformations of the Empire as a process that had to be directed and led by learned men-of-state. I have striven to show that moving beyond the limited and limiting exploration of the sciencereligion opposition can shed light on more complex conceptual dynamics involving science in the late Ottoman Empire and on their institutional embodiments.

The nineteenth century was a period of ever-expanding government intervention that not only became more intensive, but also encompassed new fields of action. These were to be attended to by expert personnel, expected to be in possession of relevant knowledge and skills, achieved via training (tahsil-i fünûn) from other skilled men or in an institution of education. This drive towards a broader, more intense and specialised government intervention is well reflected in the shifting use of the concept of nafia in the bureaucratic parlance from a broad notion of beneficial and profitable actions to a very specific meaning of "public works" such as infrastructures and urban reforms. My analysis of the conceptual links between fenn-ilm, on the one hand, and nafia, on the other, strives to underline the importance of science for restructuring the state and the economy. While this conceptual interaction first emerged in the realm of government politics, it helped shape the symbolic sphere of economy and indicates the birth of the notion of a 'national economy' that no longer was defined by the state and fiscal concerns.

Technocratic logic was by no means hegemonic in the last decades of the existence of the empire, but the use of the concept of fenn in calling for, designing and also legitimising governmental action shows that it was undoubtedly gaining weight. So does the proliferation of institutions that had fenn in their name (fen kalemleri being the most typical ones), indicating a specialised, technical character of the tasks carried out by them as well as the fact that at least part of the members or staff were supposed to be experts in a specific field; an expertise acquired through practice or formal education.

Moreover, the notion of erbab-l fenn (or, men of useful/applied science) indicates a group identity that went beyond the confines of the state administration. These men recognised one another as experts possessing knowledge and skills that were needed in the "current times" and as such, entitled to be listened to and their advice followed by the governments and by the society (whichever community of reference they might have had in mind). Thus, the institutionalisation of 'science' went together with new elite formations and eventually led to the rise of a new social group, which could claim an elite position without directly integrating the mechanisms of power. 


\section{BIBLIOGRAPHY}

\section{Primary sources}

Beydilli, Kemal (1986 [1803]). ‘ílk mühendislerimizden Seyyid Mustafa ve Nizam-1 Cedid’e dair risalesi,' in Seyyid, Mustafa, Istanbul'da Askerlik Sanati, Yeteneklerin ve Bilimlerin Durumu Üzerine Risale, Istanbul, Tüyap, 1986, pp. 17-78.

Board of Direction (1909). “Osmanlı Mühendis ve Mimar Cemiyeti'nin Tarihçesi”, Osmanlı Mühendis ve Mimar Cemiyeti Mecmuast I, pp. 3-5.

Cevdet [Engineer] (1910). Osmanlı Mühendis ve Mimar Cemiyeti Mecmuası IV, p. 98.

HAT. n. 799/37041-A, 1838; İ.HR. n. 11/556, 1841.

Hübner, Otto (1869). Ekonomi Tercüme: Fenn-i idare, Midhat, Mehmed transl., Istanbul, Cemiyet-i Ilmiye matbaası.

Layiha by Küçük Hüseyin Pasha, BOA, MD. 8882, pp. 120-122 (3 February 1797).

Mahmud Cevad Ibnü'ş şeyh Nâfî (1922/1338), Maarif-i Umûmiye Nezareti Tarihçe-i Teşkilati ve Icraati, Istanbul, Matbaa-i Âmire.

Margosian [Engineer] (1910). “Hendese-i Mülkiye Muallimlerinden Mehmed Refik Bey'e”, Osmanl Mühendis ve Mimar Cemiyeti Mecmuast IV, pp. 69-70.

Mehmed Esad (1986 [1894-1895/1312]). Mir'ât-i Mühendishane-i Berrî-i Hümâyûn, Erde S. ed., Istanbul 1986.

Mehmed Refik (1910). "Rümuzat-1 Fenniyemizin Islahı Meselesi”, Osmanlı Mühendis ve Mimar Cemiyeti Mecmuası IV, p. 69.

Mehmed Refik (1909). “Ulûm ve Fünûnda Rümuzat”, Osmanlı Mühendis ve Mimar Cemiyeti Mecmuası I, pp. 13-16.

Séid Moustapha (1807). Diatribe de l'ingénieur Séid Moustapha, sur l'état actuel de l'art militaire, du génie et des sciences, Paris, Imprimerie Impériale (ed. L. Langlès, author of the introduction; the first edition of the book in French was published in the Typographie de Scutari, Constantinople 1803).

\section{Secondary sources}

Akbaş (Kocaman), Meltem (2007-2008). 'Elektrik Mühendisi Mehmed Refik Fenmen: Osmanlı'dan Cumhuriyet'e yenilikçi bir aydın,' Osmanlı Bilimi Araştırmaları 9(1-2), pp. 101-119.

Akyürek, Göksun (2011). Bilgiyi Yeniden Inşaat Etmek: Tanzimat Döneminde Mimarlık, Bilgi ve İktidar, Istanbul, Tarih Vakfi Yurt Yayınları.

Atayman, Mustafa şevki (1984). Bir İnşaat Mühendisin Anıları, Istanbul, I.T.Ü, Inşaat Fakültesi. (2nd edition prepared by İsmail Hakkı Aksoy).

Berkes, Niyazi (1978). Türkiye'de Çağdaşlaşma, Istanbul, Doğu-Batı Yayınları.

Bocquet, Denis; Fettah, Samuel, eds. (2007). Réseaux techniques et conflits de pouvoir, Rome, École française de Rome.

Bourdieu, Pierre (1989). La Noblesse d'État. Grandes écoles et esprit de corps, Paris, Éditions de Minuit. 
Cole, Camille (2021). 'Nafi'a for the Tigris: the Privy Purse and the Infrastructure of Development in Late Ottoman Iraq, 1882-1914,' History of Science, pp.1-23. https://journals.sagepub.com/doi/ pdf/10.1177/0073275321999265

Dölen, Emre (2009). Türkiye Üniversite Tarihi I: Osmanlı Döneminde Darülfünun 1863-1922, Istanbul, Bilgi Üniversitesi Yayınları.

Erdoğan, Aynur (2013). 'Tanzimat Döneminde Modern Bilim Algısı,' Sosyoloji Dergisi 3(26), pp. 1-31.

Ferguson, Heather L. (2018). The Proper Order of Things: Language, Power, and Law in Ottoman Administrative Discourses, Stanford, Stanford University Press.

Fortna, Benjamin (2002). Imperial Classroom: Islam, Education and the State in the Late Ottoman Empire, Oxford, Oxford University Press.

Fredj, Claire (2014). 'Quelle langue pour quelle élite ? Le français dans le monde médical ottoman à Constantinople (1839-1914),' in Işıksel, Güneş; Szurek, Emmanuel eds., Turcs et Français: une histoire culturelle, Rennes, Presses universitaires de Rennes, pp. 73-98.

Günergun, Feza (2011). 'The Ottoman Ambassador's Curiosity Coffer: Eclipse Prediction with De La Hire's 'Machine' Crafted by Bion of Paris,' in Günergun, Feza; Raina, Dhruv eds., Science between Europe and Asia, Leiden, Springer, pp. 103-123.

Hanioğlu, şükrü (1984). 'Osmanlı Aydınındaki Değişme ve Bilim,' Toplum ve Bilim 27, pp. 183-192. Hitzel, Frédéric (1995). 'Les écoles de mathématiques turques et l'aide française (1775-1798),' in Panzac, Daniel ed., Histoire économique et sociale de l'Empire Ottoman et de la Turquie (1326-1960), Paris, pp. 813-825.

İhsanoğlu, Ekmeleddin (1992). ‘Tanzimat Öncesi ve Tanzimat Dönemi Osmanlı Bilim Ve Eğitim Anlayışı,’ 150. Yılında Tanzimat, Ankara, Türk Tarih Kurumu, pp. 335-395.

Kapucu, Naim; Palabıyık, Hamit (2008). Turkish Public Administration: From Tradition to the Modern Age, Ankara, ISRO.

Kaçar, Mustafa (2000). 'The Development in the Attitude of the Ottoman State Towards Science and Education and the Establishment of the Engineering Schools (Mühendishanes),' in Ihsanoğlu, Ekmeleddin; Djebbar, Ahmed; Günergun, Feza eds., Science, Technology and Industry in the Ottoman World, Brepols, Turnhout, pp. 81-90.

Kaçar, Mustafa (1996). Osmanlı Devleti'nde Bilim ve Eğitim Anlayışındaki Değişmeler ve Mühendishanelerin Kuruluşu, unpublished Doctoral Thesis, University of Istanbul, Istanbul.

Kara, Ismail (2003). "Les notions de 'science' (ulûm, fünûn) et d"art' (san'at) à l'âge des Réformes ottomanes," in Anastassiadou-Dumont, Méropi ed., Médecins et ingénieurs ottomans à l'âge des nationalismes, Paris Istanbul, Maisonneuve et Larose/Institut français d'études anatoliennes, pp. 31-47.

Keskin, Nuray E. (2010). ‘Yönetim Olgusu Üzerine 1909 Tarihli Bir Makale: "Sosyal Bilimler Ve Yönetim Bilimi”,' Memleket, Siyaset, Yönetim 5(12), pp.181-200.

Kırmızı, Abdülhamit (2012). 'Going Round the Province for Progress and Prosperity: Inspection Tours and Reports by Late Ottoman Governors,' Studies in Travel Writing 16(4), pp. 387-401.

Kolland, Daniel (2016). Between Universal Progress and Particular Plight: Fin-de-Siècle Technology Discourses in Servet-i Fünûn and al-Muqtațaf, Master Thesis, Munich Ludwig Maximilian University.

Koselleck, Reinhart (1993). Futuro pasado. Para una semántica de los tiempos históricos, Barcelona, Paidós. 
Küçük, Harun (2019). Science without Leisure: Practical Naturalism in Istanbul, 1660-1732, Pittsburg, University of Pittsburgh Press.

Mardin, şerif (2018). Türk Modernleşmesi, Istanbul, İletişim Yayınları.

Martykánová, Darina (2014). 'Ottoman Engineers: The Redefinition of Expert Identities during the Reign of Abdülhamid II and the Early Years of the Second Constitutional Period,' Turcica 45, pp. 125-156.

Martykánová, Darina (2010). Reconstructing Ottoman Engineers. Archaeology of a Profession (1789-1914), Pisa, Edizioni Plus.

Martykánová, Darina (2009). 'Matching Sharia and “Governmentality”: Muslim Marriage Legislation in the Late Ottoman Empire,' in Xydopoulos, Ioannis; Gémes, Andreas; Peyrou, Florencia eds., Institutional Change and Stability. Conflicts, Transitions, Social Values, Pisa, Edizioni Plus, pp. 153-175.

Martykánová, Darina; Kocaman, Meltem (2018). ‘A Land of Opportunities: Foreign Engineers in the Ottoman Empire,' in Roldán, Concha; Brauer, Daniel; Rohbeck, Johannes eds., Philosophy of Globalization, Berlin, De Gruyter, pp. 237-251.

Martykánová, Darina; Pan-Montojo, Juan (2020). 'Los constructores del Estado: los ingenieros españoles y el poder público en el contexto europeo (1840-1900),' Historia y Política 43, pp. 57-86.

Picon, Antoine (2007). 'French Engineers and Social Thought, 18-20th Centuries: An Archaeology of Technocratic Ideals,' History and Technology 23, pp. 197-208.

Porter, Theodore M. (1995). Trust in Numbers: The Pursuit of Objectivity in Science and Public Life, Princeton, Princeton University Press.

Sariyannis, Marinos (2019). A History of Ottoman Political Thought Up to the Early Nineteenth Century, Leiden, E.I.J. Brill.

Sariyannis, Marinos (2013). 'Ruler and State, State and Society in Ottoman Political Thought,' Turkish Historical Review 4, pp. 92-126.

Sigalas, Nikos (2007). 'Devlet et État: du glissement sémantique d'un ancien concept du pouvoir au début du XVIII ${ }^{\mathrm{e}}$ siècle ottoman,' in Grivaud, Gilles; Petzmezas, Socrate eds., Byzantina et Moderna: mélanges en l'honneur d'Hélène Antoniadis-Bibicou, Athens, Alexandria, pp. 385-415.

Tekeli, İlhan; İlkin, Selim (1994). ‘Mustafa Celaleddin Bey’in ‘Bir Eyaletin Islah ve İmari Hakkında Mükaleme” Adlı Risalesi ve 19. Yüzyıla Osmanlı İmparatorluğu'nda İmar Kavramının Gelişimi Üzerine Düşünceler,' in XI. Türk Tarih Kongresi, Ankara, 5-9 September 1990, Ankara, pp. 1469-1492.

Terzioğlu, Derin (2013). ‘Where 'İlm-i Ḥāl Meets Catechism: Islamic Manuals of Religious Instruction in the Ottoman Empire in the Age of Confessionalization,' Past \& Present 220(1), pp. 79-114.

Uluçay, Çağatay; Kartekin, Enver (1958). Yüksek Mühendis Okulu, Istanbul, Berksoy Matbaası. Yalçınkaya, M. Alper (2015). Learned Patriots: Debating Science, State and Society in the Nineteenth Century Ottoman Empire, Chicago London, University of Chicago Press.

Yıldız, Aytaç; Gündüz, Mustafa (2019). 'Maarif: Transformation of a Concept in the Ottoman Empire at the Beginning of the Nineteenth Century,' History of Education 48(3), pp. 275-296. 


\section{NOTES}

1. In this pursuit, I neither wish to not will avoid including aspects that are now understood as discrete from science and encompassed by the term technology.

2. Maarif, an important knowledge-related concept that sometimes interacted and overlapped with ilm and fenn, has been explored in a recent valuable study by (Yıldız; Gündüz 2019).

3. In this particular aspect I disagree with Akyürek's interpretation of the Ottoman use as different from the European one, based on the assumption that in Europe, the difference between sciences as theoretical and arts as practical was clear and well established.

4. HAT. n. 799/37041-A, 1838; İ.HR. n. 11/556, 1841.

5. Beydilli 1986 [1803]: 17-78. The Ottoman version of the Diatribe published in a transcribed version (Ottoman in Latin letters), 69-78.

6. Medicine, with its long-established scientific credentials and, at the same time, obvious applicability and technical aspects, can be an interesting exception. I thank the reviewer no. 2 for her/his observation that physicians interchangably used tatbik and san'at to refer to technique of drug preparation and, hazakat to talk about technical skill.

7. Küçük Hüseyin Pasha, "Layiha", BOA, MD. 8882, 120-122, dated to 3rd of February 1797. A complete transcription of the manuscript in Kaçar 1996: 196-200.

8. Küçük Hüseyin Pasha, "Layiha”, BOA, MD. 8882, 120-122, dated to 3rd of February 1797; Séid Moustapha 1807 (ed. L. Langlès, author of the introduction; the first edition of the book in French was published in the Typographie de Scutari, Constantinople 1803).

9. Küçük Hüseyin Pasha, "Layiha cit.”.

10. Küçük Hüseyin Pasha, "Layiha cit."

11. Layiha of Bekir Pasha, director of the Military School of Engineers, 1847. This project of reform of the engineering school is reproduced in Mehmed Esad 1986 (1894-1895/1312): 74-77.

12. In his work on the history of the Ottoman Administration of Public Education, Mahmud Cevad quotes this report from 1869. Mahmud Cevad Ibnü'ş şeyh Nâfî (1922/1338). Also quoted in Kara 2003: 33.

13. Ebubekir Ratib Efendi'nin Neçe Sefaretnamesi in Hanioğlu 1984: 184.

14. This is not to say that the concern about the people's ignorance was a particularly novel phenomenon of the mid-nineteenth century, in Europe and in the Ottoman lands. For its earlier manifestations: Küçük 2019; Terzioğlu 2013.

15. The translation and interpretation of the Ottoman text is mine.

16. Hübner 1869.

17. For an example of Bedi Nuri's work: Keskin 2010.

18. http://www.iranicaonline.org/articles/dar-al-fonun-lit

19. Ibid.

20. The quote from the "Meclis-i Vâlâ maztabası", Takvim-i Vekayi 303, 1262, reproduced in Akyürek 2011: 103.

21. Board of Direction 1909.

22. Mehmed Refik 1909: 13-16, and 1910: 69, a reply by engineer Margosian 1910: 69-70; a comment by engineer Cevdet: Ibid., 98 . 


\section{ABSTRACTS}

The nineteenth century was a period of ever-expanding government intervention that not only became more intensive, but also encompassed new fields of action. These were to be attended to by expert personnel, expected to be in possession of relevant knowledge and skills, achieved via training (tahsil-i fünûn) from other skilled men or in an institution of education. This drive towards a broader, more intense and specialised government intervention is well reflected in the shifting use of the concept of nafia in the bureaucratic parlance from a broad notion of beneficial and profitable actions to a very specific meaning of "public works" such as infrastructures and urban reforms. My analysis of the conceptual links between fenn-ilm, on the one hand, and nafia, on the other, strives to underline the importance of science for restructuring the state and the economy. While this conceptual interaction first emerged in the realm of government politics, it helped shape the symbolic sphere of economy and indicates the birth of the notion of a 'national economy' that no longer was defined by the state and fiscal concerns.

\section{INDEX}

Keywords: Late Ottoman Empire, science and technology, elites, state and economy

\section{AUTHOR}

\section{DARINA MARTYKÁNOVÁ}

Universidad Autónoma de Madrid

darina.martykanova@uam.es 